\title{
Exploring the Effects of Social Media on Interpersonal Communication among Family Members
}

\author{
Ayla G. Lopez and Kennet G. Cuarteros
}

\begin{abstract}
Communication is essential toward all families and given the technology that we have today, Facebook has been one of many social media sites that lets people stay connected whereever they may be, although, not all members of the family are in to using Facebook to communicate with their loved ones. This study aims to determine the effects of social media on interpersonal communication among family members, in particular, it analyzes the effectiveness of Facebook and family communication. In connection with this, the emphasis of this study is the effects of social media on the quality of interpersonal communication skills among family members. A sample of $25 \%$ of 120 individuals from four different colleges during the 2016-17 school year were the respondents of this study. A questionnaire was given to the respondents which included their profile, number of hours and activities on Facebook, and lastly the quality of their interpersonal communications with their family members. The results of the study show that communicating through Facebook more than likely leads to misunderstandings among family members as the messages are not expressed properly. Hence, a family must take time to talk and interact with each other personally in order to avoid these kinds of conflicts and maintain a good family relationship.
\end{abstract}

Keywords: social media, communication, interpersonal communication, family

Ayla G. Lopez has a Bachelor of Science in Technology Communication Management degree from the University of Science and Technology in Southern Philippines.

Kennet G. Cuarteros is an Associate Professor II, Department of Applied Mathematics, University of Science and Technology in Southern Philippines. A recent publication includes: Classifying Student's Engagement in Computer Games using Linear Discriminant Analysis. 


\section{Introduction}

Background of the Study

Social media provides essentials that individuals need to be updated, to communicate, and to be educated. Teenagers use media communication and digital devices to connect with individuals around the world as their primary form of socialization (Hill, 2015). However, through its wide access communication, for example using Facebook, many families misinterpret the messages they receive. When this happens, barriers can be created within the family. To respond to this concern, family members will have to monitor each other when using Facebook.

Monitoring the family member's usage on Facebook can be a means to guide them in order to reduce misunderstandings in communication. According to its co-founder and chief executive officer, Facebook "leads to a better understanding of the lives and perspectives of others" (Zuckerberg, 2012). Hence, each member of the family should know how to discipline each other without losing trust so that conflicts can be avoided.

According to Kuss and Griffiths (2011), Facebook has become a global consumer phenomenon that has more than 500 million users active in the Facebook community. Between $55 \%$ and $82 \%$ of teenagers and young adults use a Social Network Service (SNS) on a regular basis. A large survey of college students from several universities in the mid-west United States found that $91 \%$ of respondents use Facebook (Wiley \& Sisson, 20016). Many users experience self-esteem issues and are trying to avoid the real world. There is also an implication of internet addiction, which is contributed to the individuals who have spent more time with Facebook. As college students spend more time online than any prior generation, it is important to know what gratifications they seek and obtain from new media (Sheldon, 2008). Lenhart, Purcell, Smith and Zickuhr's research (2010) from September, 2009 showed that 93\% of teenagers, aged 12 to 17 were using the Internet (e.g. Facebook), while a study from December, 2009 indicated 93\% of young adults aged 18 to 29 were using the Internet. During the same time, $81 \%$ of adults aged 30 to 49 were using the Internet and $38 \%$ of users over the age of 65 were using the Internet. Thus, it is suggested that the increasing number of hours or frequency in the use of social media may have an increasing negative effect in communication and interaction among family members.

An article from Philstar highlights a trend of Filipinos to work abroad, which also creates a gap or distance in communication. About $10 \%$ or approximately 11 million Filipinos are obligated to work abroad in order to buy happiness and the best education available for their children (Bondoc, 2014). The use of Facebook is their way of connecting with family members as it helps to fill the gap in communication.

Furthermore, monitoring the family member's social interactions may also lessen conflict among members of the family. Each of the family members may perhaps consider face-to-face communication rather than the indirect, nonpersonal communication through the social media such as Facebook. This study aims to explore the effects of social media on interpersonal communication among family members. 


\section{Theoretical Considerations}

This study was anchored on Family System Theory, Uses and Gratification Theory and Technological Determinism. Kerr (2000) quoted Bowen's idea that the Family System Theory states that individuals cannot be understood in isolation from one another, but rather as part of their family, as the family is an emotional unit. Families are systems of interconnected and interdependent individuals, none of whom can be understood in isolation from the system. It underlines the role of the family members in controlling one another, for example, when they are using Facebook.

Ruggiero (2000) in his work cited Blumers and Katz who stated that in Uses and Gratification Theory, the media cannot affect an individual if they are not involved in using it or the messages in the media. It emphasizes also how family members' desire to satisfy their needs through the use of Facebook. However, those who are not that exposed to Facebook are likely to have more time together with their families.

The results of technology on teens can be loneliness, depression and anxiety which originates from an excessive internet use to gain emotional support, encounter new people and connect with individuals near and far (Selfhout et al., 2009). From this, teenagers use Facebook as their way of expressing their thoughts and feelings when they feel neglected by their families.

Adler (2008) quoted Macluhan's idea on Technological Determination (TD). To simply put it, it is the idea that technology has important effects in our lives. This idea figures prominently in the popular imagination and political rhetoric, for example in the idea that the Internet is revolutionizing the economy and society. Hence, Facebook enables users to create social change whether it is negative or positive.

The study showed how teens change their behavior when they are engaging in SNS. Teenagers update and post everyday on isses relating to fashion trends, body image, the hottest hangout, or sports. They seek attention from the feedback or comments they receive to build up or enhance their self-esteem. They can feel pleasure, obtain a good self-image and disclose opinions which in turn, can be confirmed by other people's opinion about their particular post (Hill, 2015). In the case of social media, Facebook becomes part of a person's life and within the family, the siblings, particularly the teens, are more prone to this kind of behavior.

Gender as one of the independent variables in this study as it is vital in distinguishing which gender is more active and is a directly affected user on Facebook. According to Chan, et al. (2005), $40.5 \%$ of the variance in user is related to the satisfaction that they obtain from the experience. The outcome indicates that the satisfaction of male users in using SNS plays a significant role in entertaining them, whereas female users gave importance to maintaining relationships rather than determining satisfaction. It emphasizes that family members' usage on Facebook can either satisfy them by means of entertainment, or by means of maintaining their relationship to one another.

Social media, particularly Facebook, one of the variables in this study, refers to the respondents' use in terms of the number of hours and activities that they engage in. Facebook was the first social networking site to exceed 1 billion registered accounts and as of January 2016, there were 1.55 billion active users online (Mei-Pochtler, 2016). Consequently, every family member should know how to limit their usage on Facebook to avoid misunderstandings. 
According to Lenhart (2012), teens' social skills are decreasing because of their lack of faceto-face communication. This point was also agreed to by Steiner-Adair and Barker (2013) who indicated that teens would rather obtain their information and advice from people on their social networking sites rather than communicating face-to-face. For that reason, every family member should learn how to comfort each other or to communicate with them personally in order to maintain interpersonal relationships.

The quality of interpersonal communication with parents and siblings depends on the level of interpersonal communication within the family. According to Vera (2015), the quality of interpersonal communication can be increased through face-to-face interaction and media but it depends on the context and situation. Face-to-face interaction and media communication have the same quality if it is in a normal context while communication through media is more appropriate than face-to-face in conflicting contexts. In general, they agreed that the development of communication technology affects the quality of communication in social context. Hence, the effectiveness of communication may vary to face-to-face or through social media. Face-to-face communication is healthy in s family's normal everyday conversation while during conflicting situations, social media communication is more appropriate.

The rise of technology affects the family's ability to communicate in person as they will have less quality time with each other. Today's generation of teenagers is more active when it comes to social media communication and interaction. Given the theories mentioned above, this study will explore the effect of social media, particularly Facebook, on the quality of communication among family members.

\section{Methodology}

This study aimed to explore the effects of social media on quality of interpersonal communication among family members. Specifically, it determined the following: (1) the profile of the respondents in terms of gender and use of social media; (2) the level of quality of interpersonal communication of the respondents with parents, siblings and extended family; (3) the significant difference in the respondent's level of interpersonal communication; and (4) the significant effect of social media on interpersonal communication among family members.

This study was conducted at Mindanao University of Science and Technology, C.M Recto, Lapasan, Cagayan de Oro City during the second semester of 2016. To interpret the results, a descriptive research design was used in this study. It used the procedure of random sampling, specifically cluster random sampling. The respondents were one (1) random section of selected courses of the College of Arts and Sciences (CAS); Bachelor of Science in Technology Communication Management (BSTCM), College of Policy Studies, Education and Management (CPSEM); Bachelor of Secondary Education, Major in Technology and Livelihood Education (BSED-TLE), College of Industrial and Information Technology (CIIT); Bachelor of Science in Electronics and Communication Technology (BSECT), and College of Engineering and Architecture (CEA); Bachelor of Science in Electronics Communication Engineering (ECE) since their courses are related to Technology and Communication. 120 respondents were considered for this study. There were 30 respondents in each class that were randomly selected. In addition, $42.5 \%$ were male and $57.5 \%$ were female. 
For data gathering, the researchers made a cover letter to seek the permission from the Adviser and Technology Communication Management Department Chairperson. The cover letter was given to the Chairman of the selected Departments in order for the researchers to ask for a copy of the second year students' class schedules relating to the school year of 2016-2017. The cover letter was signed by the Chairperson and was presented to the instructors of the respondents. During the data gathering process, the researchers explained the purpose of this study to the respondents. Before the respondents began to answer, the researchers first read and clarified the instructions written on the questionnaire.

The questionnaire had three parts. Part I, contained their profile as students including heir name and gender. Part II asked questions about their use of Social media (i.e. their number of hours and activities on Facebook). Part III asked general questions about their quality of interpersonal communications with their parents, siblings and extended family members.

The data was analyzed through the use of a descriptive statistical tool such as mean, percentage, and standard deviation in order to describe the responses of the respondents.

These were the processes and statistical treatments used in this study in order to determine the effects of social media on interpersonal communication among family members.

\section{Highlights of Findings and Discussion}

Our purpose in conducting this study was to explore the effects of social media on interpersonal communication among family members. According to Al-Khaddam (2013), extensive use of social networks by these young people reduces their personal interactions with other members of the community. With this, miscommunications will occur not only through friends but also within the family. As Ellison et al. (2007) noted, college students did not use Facebook to keep up with parents nor with strangers. Only about $9 \%$ of our young adults sampled used Facebook to make new friends. Moreover, this will help determine whether communication through Facebook is more effective on family conversations than the traditional face-to-face communication or vice versa.

Table 1 presents the distribution of the respondents according to their gender. It further shows that most of the respondents are female students. In 2015, the majority of American Facebook users were $77 \%$ female while $23 \%$ were male (Duggan, 2015). Thus, this proves that female users are more exposed or engaged on Facebook than males.

\section{Table 1: Frequency Distribution of the Respondents by Gender}

\begin{tabular}{|c|c|c|}
\hline Gender & Frequency & Percentage \\
\hline Female & 69 & 57.50 \\
\hline Male & 51 & 42.50 \\
\hline Total & 120 & 100 \\
\hline
\end{tabular}


As shown in Table 2.1, most of the students spent one to two hours on Facebook with $39.17 \%$ of the total number of respondents. However, there are students who spend less than an hour, for the reason that they only check their notifications and messages, and browse the newsfeed. In 2007, U.S. college students reported using Facebook an average of 10 to 30 minutes daily (Ellison et al., 2007), while in 2008, students usually spent 47 minutes a day on Facebook. Fifty-four percent of the respondents logged into their account several times per day. Twentyseven percent logged in once per day (Sheldon, 2008). So, this shows that for the past 9 years there has been changes in the number of hours that the users spent in using Facebook per day.

Table 2.1: Respondents' Hours Spent in Facebook

\begin{tabular}{|r|c|c|}
\hline No. of Hours Spent & Frequency & Percentage \\
\hline Less than an hour & 31 & 25.83 \\
\hline $1-2$ hours & 47 & 39.17 \\
\hline $3-4$ hours & 31 & 25.83 \\
\hline More than 4 hours & 11 & 9.17 \\
\hline Total & 120 & 100 \\
\hline
\end{tabular}

In an interview, the respondents matched the results that students mostly spend one to two hours a day using Facebook. In addition, they use Facebook to entertain themselves and to be updated on the latest announcements, trends or news.

As for their activities, Table 2.2 presents the different Facebook activities that students usually do. Furthermore, it is shown that students do good in some activities like share and like posts, check comments, check messages, and check group activities for educational purposes. However, the students do somewhat good for the rest of the activities. On the average, students do somewhat good in Facebook activities which shows the usual activities an individual does on Facebook. In relation to Sheldon (2008), results indicate that most students go on Facebook to maintain relationships with people they know. Their purpose is to send messages, post messages on their walls, keep in touch with their friends, or to reach people who are difficult to contact. Others use it for entertainment, to develop relationships, to meet new people, and to ease their boredom. For that reason, students use Facebook to build a relationship with other people, especially their families. 
Table 2.2: Facebook Activities

\begin{tabular}{|c|l|c|c|c|}
\hline$\#$ & \multicolumn{1}{|c|}{ Facebook Activities } & Mean & SD & Description \\
\hline 1 & Update Status (videos, selfies, create albums, etc.) & 2.92 & 1.07 & SG \\
\hline 2 & Share and like posts & 2.23 & 1.08 & G \\
\hline 3 & Check comments & 2.32 & 1.12 & G \\
\hline 4 & Check messages & 1.72 & 0.95 & G \\
\hline 5 & Check friends' post on Facebook & 2.73 & 1.11 & SG \\
\hline 6 & Check group activities for educational purposes & 1.93 & 1.00 & G \\
\hline 7 & Follow new trends & 3.22 & 1.07 & SG \\
\hline 8 & Follow and check updates of your favorite celebrities & 3.48 & 1.22 & SG \\
\hline 9 & Follow and check updates of your TV shows & 3.37 & 1.16 & SG \\
\hline 10 & Follow and check current events and news & 2.64 & 1.14 & SG \\
\hline \multirow{2}{*}{ Overall } & $\mathbf{2 . 6 5}$ & $\mathbf{1 . 0 9}$ & SG \\
\hline
\end{tabular}

Most of the students check their messages on Facebook to communicate efficiently. Moreover, the majority of the students do not use Facebook to follow and check updates of their favourite celebrities.

Social media has grown by leaps and bounds for the past few years. It is used as a platform to stay connected with people anytime they want. Facebook is where we extend our communications to our family, friends and relatives. Table 3 shows the level of interpersonal communication of the students with respect to Facebook. It is evident from the response that students somewhat maintain good communication with their parents, siblings, and even with their extended families. However, there is a noticeably poor response when it comes to a discussion of private matters toward the extended family members. According to Burke et al. (2013), in some cases, there are family relationships where one party is not on Facebook (i.e. either the parent or the child is less techy and doesn't want to get involve on Facebook). In this scenario, we may connect it to the idea that it is hard to discuss private matters with extended families because it may cause a negative result in the end. Private matters would be best discussed with immediate family members. 
Table 3: Level of Interpersonal Communication (Facebook)

\begin{tabular}{|c|c|c|c|c|c|}
\hline \multicolumn{6}{|c|}{ A. Through Facebook Communication } \\
\hline \# & Facebook Activities & Family Members & Mean & SD & Description \\
\hline \multirow{3}{*}{1} & \multirow{3}{*}{ Understand messages received } & Parents & 2.39 & 1.45 & G \\
\hline & & Siblings & 2.31 & 1.20 & G \\
\hline & & Extd. Family Members & 2.56 & 1.27 & SG \\
\hline \multirow{3}{*}{2} & \multirow{3}{*}{$\begin{array}{l}\text { Properly respond words being } \\
\text { communicated }\end{array}$} & Parents & 2.20 & 1.38 & G \\
\hline & & Siblings & 2.37 & 1.24 & $\mathrm{G}$ \\
\hline & & Extd. Family Members & 2.73 & 1.21 & SG \\
\hline \multirow{3}{*}{3} & \multirow{3}{*}{ Shows appreciation } & Parents & 2.08 & 1.38 & G \\
\hline & & Siblings & 2.08 & 1.18 & G \\
\hline & & Extd. Family Members & 2.41 & 1.33 & G \\
\hline \multirow{3}{*}{4} & \multirow{3}{*}{$\begin{array}{l}\text { Intense emotion (positive } \\
\text { /negative) is clear }\end{array}$} & Parents & 2.68 & 1.30 & SG \\
\hline & & Siblings & 2.86 & 1.23 & SG \\
\hline & & Extd. Family Members & 3.16 & 1.19 & SG \\
\hline \multirow{3}{*}{5} & \multirow{3}{*}{ Clear in sharing ideas } & Parents & 2.62 & 1.37 & SG \\
\hline & & Siblings & 2.67 & 1.28 & SG \\
\hline & & Extd. Family Members & 3.10 & 1.27 & SG \\
\hline \multirow{3}{*}{6} & \multirow{3}{*}{$\begin{array}{l}\text { Discuss about private matter } \\
\text { (school problems, love life } \\
\text { and etc.) }\end{array}$} & Parents & 2.97 & 1.48 & SG \\
\hline & & Siblings & 3.23 & 1.35 & SG \\
\hline & & Extd. Family Members & 3.72 & 1.19 & $\mathrm{P}$ \\
\hline 7 & & Parents & 2.47 & 1.38 & G \\
\hline
\end{tabular}




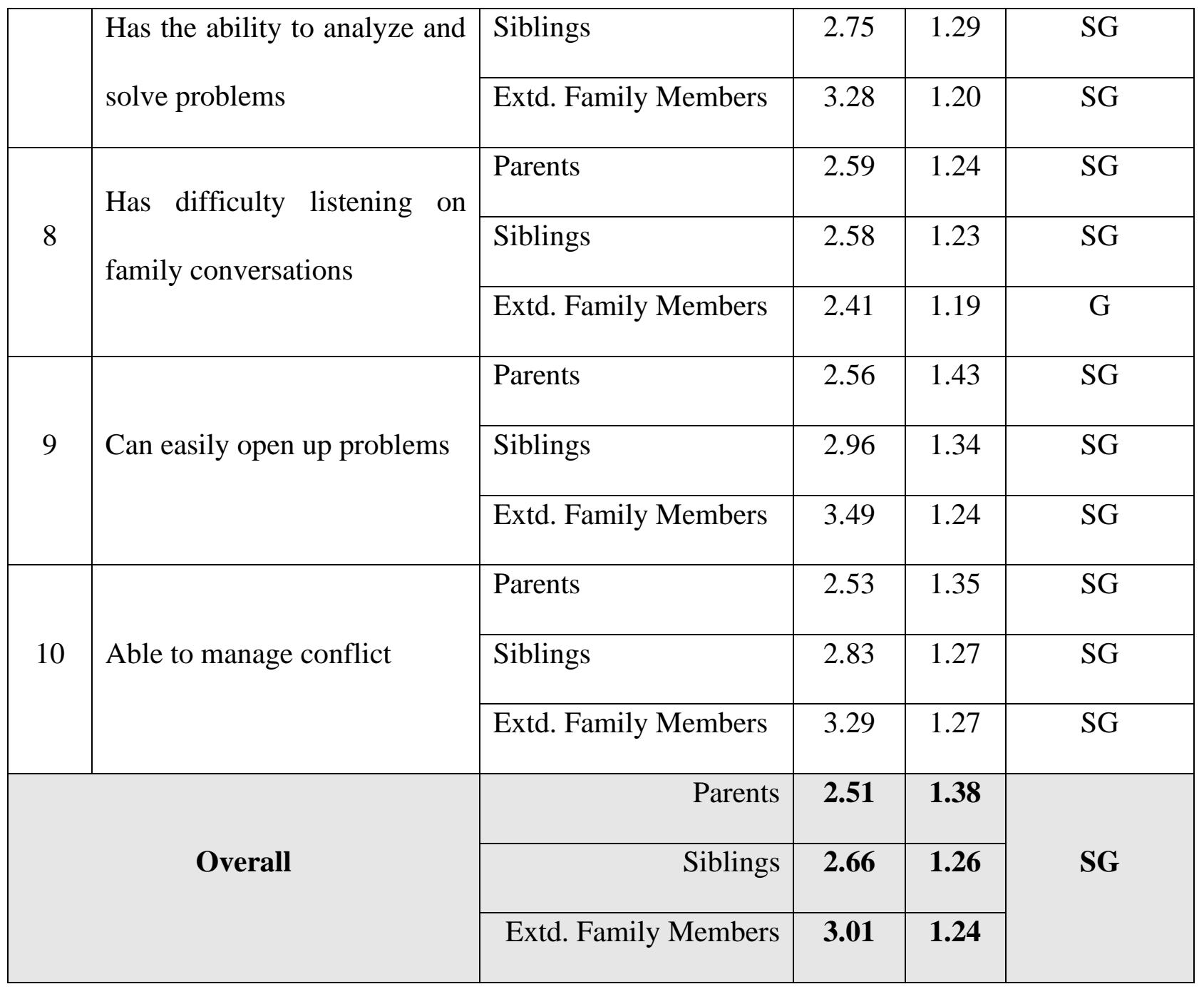

Legend: VG: Very Good $\quad$ SG: Somewhat Good $\quad$ G: Good $\quad$ P: Poor $\quad$ VP: Very Poor

In an interview, the respondents agreed that with the results that students would prefer to show appreciation towards their parents by use of Facebook. In place of, they use Facebook to show how much they care for their parents as they cannot express it personally. In addition, they chose to communicate via face-to-face with their families when it comes to private matters.

Even if social media helps us to reconnect and be connected with our loved ones, it is better to communicate with them personally as all involved parties cannot only hear what is being said but they can also sense body movements, facial expressions, and feel the emotions, that provides key information so that they can clearly understand the meaning behind the words. Table 4 shows the level of interpersonal communication via face-to-face communication among the respondents' family. It is observed that students maintain good condition of communication among family members. This is a good indicator that personal communication is the best way to further improve 
the relationship of the family. The table also shows that there is a very good connection between the students and their parents with regards to the understanding of messages being received, probably because parents tend to understand their child no matter what issue is discussed. As Burke et al. (2013) noted, parent-child communication may be very different in private, with more intimate disclosure, complaining or nagging. Thus, face-to-face communication is effective in disclosing family matters to avoid miscommunication.

Table 4: Level of Interpersonal Communication (Face to face)

\begin{tabular}{|c|c|c|c|c|c|}
\hline \multicolumn{6}{|c|}{ B. Through One-on-one / Personal Communication } \\
\hline \# & Facebook Activities & Family Members & Mean & SD & $\overline{\text { Description }}$ \\
\hline \multirow{3}{*}{1} & \multirow{3}{*}{ Understand messages received } & Parents & 1.49 & 0.80 & VG \\
\hline & & Siblings & 1.95 & 1.09 & $\mathrm{G}$ \\
\hline & & Extd. Family Members & 2.41 & 1.27 & $\mathrm{G}$ \\
\hline \multirow{3}{*}{2} & \multirow{3}{*}{$\begin{array}{l}\text { Properly respond words being } \\
\text { communicated }\end{array}$} & Parents & 1.53 & 0.76 & G \\
\hline & & Siblinos & 203 & 111 & $\mathrm{G}$ \\
\hline & & Extd Family Members & 239 & 130 & G \\
\hline \multirow{3}{*}{3} & \multirow{3}{*}{ Shows appreciation } & Parents & 1.53 & 0.89 & $\mathrm{G}$ \\
\hline & & Siblings & 1.86 & 1.07 & $\mathrm{G}$ \\
\hline & & Extd. Family Members & 2.33 & 1.24 & $\mathrm{G}$ \\
\hline \multirow{3}{*}{4} & \multirow{3}{*}{$\begin{array}{l}\text { Intense emotion } \\
\text { (negative) is clear }\end{array}$} & Parents & 2.10 & 1.08 & G \\
\hline & & Siblings & 2.50 & 1.12 & $\mathrm{G}$ \\
\hline & & Extd. Family Members & 2.88 & 1.21 & SG \\
\hline \multirow{3}{*}{5} & \multirow{3}{*}{ Clear in sharing ideas } & Parents & 1.80 & 0.936 & $\mathrm{G}$ \\
\hline & & Siblings & 2.38 & 1.17 & $\mathrm{G}$ \\
\hline & & Extd. Family Members & 2.92 & 1.30 & $\mathrm{SG}$ \\
\hline
\end{tabular}




\begin{tabular}{|c|c|c|c|c|c|}
\hline \multirow{3}{*}{6} & \multirow{3}{*}{$\begin{array}{l}\text { Discuss about private matter } \\
\text { (school problems, love life and } \\
\text { etc.) }\end{array}$} & Parents & 2.09 & 1.22 & G \\
\hline & & Siblings & 2.43 & 1.28 & G \\
\hline & & Extd. Family Members & 3.18 & 1.32 & SG \\
\hline & \multirow{3}{*}{$\begin{array}{l}\text { Has the ability to analyze and } \\
\text { solve problems }\end{array}$} & Parents & 1.78 & 0.97 & $\mathrm{G}$ \\
\hline 7 & & Siblings & 2.40 & 1.18 & $\mathrm{G}$ \\
\hline & & Extd. Family Members & 2.95 & 1.28 & SG \\
\hline \multirow{3}{*}{$\varepsilon$} & \multirow{3}{*}{$\begin{array}{l}\text { Has difficulty listening on } \\
\text { family conversations }\end{array}$} & Parents & 3.21 & 1.26 & SG \\
\hline & & Siblings & 2.93 & 1.19 & SG \\
\hline & & Extd. Family Members & 2.73 & 1.13 & SG \\
\hline \multirow{3}{*}{9} & \multirow{3}{*}{ Can easily open up problems } & Parents & 2.07 & 1.11 & G \\
\hline & & Siblings & 2.61 & 1.30 & SG \\
\hline & & Extd. Family Members & 3.18 & 1.29 & SG \\
\hline \multirow{3}{*}{10} & \multirow{3}{*}{ Able to manage conflict } & Parents & 1.92 & 1.03 & $\mathrm{G}$ \\
\hline & & Siblings & 2.45 & 1.17 & G \\
\hline & & Extd. Family Members & 2.96 & 1.26 & SG \\
\hline \multirow{3}{*}{\multicolumn{2}{|c|}{ Overall }} & Parents & $\mathbf{1 . 9 5}$ & 1.00 & G \\
\hline & & Siblings & 2.35 & 1.17 & G \\
\hline & & Extd. Family Members & 2.79 & 1.26 & SG \\
\hline
\end{tabular}

Legend: VG: Very Good SG: Somewhat Good G: Good P: Poor VP: Very Poor

An interview was conducted to support the results by which the students would more likely prefer having face-to-face communication in communicating with their parents rather than through Facebook, for the purpose of having a better understanding of each other. 
Table 5 shows the statistical test of the difference between Facebook and personal (faceto-face) communications. The result implies that there is a significant difference. With the difference of 0.362 , it shows that students tend to use Facebook with the mean 2.728 than personal communication with a mean 2.366 . This may be the result of a constant use of social media by our students.

Table 5: T-test of Level of Interpersonal Communication

\begin{tabular}{|c|c|c|c|c|}
\hline Communication & Mean & t-value & p-value & Remark \\
\hline Facebook & 2.728 & \multirow{2}{*}{4.24} & \multirow{2}{*}{0.000} & Significant \\
\cline { 1 - 2 } Personal & 2.366 & & & \\
\hline
\end{tabular}

*significant at 0.05 level of significance

As shown in Table 6, the p-value is less than the level of significance. This further implies that, if one is using social media, he/she is creating connections to other people. The result of the study of Al-Khaddam (2013) shows that there are significant effects between the use of Facebook and interpersonal communications with their family and to other people and the number of hours of using Facebook. Thus, opening an atmosphere of interaction and an exchange of information will lead to meaningful conversation. Moreover, the positive relationship between the variables shows the trend that the more students use social media, the more they communicate with other people.

Table 6: Correlation Between Social Media and Interpersonal Communication

\begin{tabular}{|c|c|c|c|c|}
\hline $\begin{array}{c}\text { Independent } \\
\text { Variable }\end{array}$ & $\begin{array}{c}\text { Dependent } \\
\text { Variable }\end{array}$ & $\begin{array}{c}\text { Pearson } \\
\text { Correlation } \\
\text { Coefficient }\end{array}$ & P-Value & Remark \\
\hline Social Media & $\begin{array}{c}\text { Interpersonal } \\
\text { Communication }\end{array}$ & 0.214 & 0.019 & Significant \\
\hline
\end{tabular}

*significant at 0.05 level of significance 


\section{Conclusion and Recommendations}

With the advent of technology, there are many ways to communicate. Aside from face-toface communication, we also have social media. Social media has become more prevalent in society. Research regarding human interaction and social media has also increased. One of the most widely used social media forms is Facebook. In this study, the researchers showed the effects of social media, particularly Facebook, on interpersonal communications among family members. Results show that Facebook helps to elevate interpersonal communication among family members. Facebook provides a venue for people who struggle to communicate effectively by facilitating a comfortable, nonthreatening means of communication (Rosenwald, 2011). Facebook enables members to open up themselves that they cannot do face-to-face. Moreover, Facebook is helpful in communication especially for students who spend most of their time in school and have less face-to-face communication with their parents. Based on the results on our survey, they used Facebook as a tool of communication with their parents whenever they are in school. Facebook can also alleviate conflicts in the family.

Given the results, the whole family should have time to talk to each other personally. The students should also learn to express their feelings towards their parents and other family members to avoid misunderstandings. In addition, if face-to-face communication may not be possible with some members of the family for whatever their reasons may be, there should be enough understanding towards each other to maintain the balance of their relationship. If misunderstandings occur and personal communication is not possible, then Facebook would be of great help with its new features where you can record your voice and send it, or both parties can do video call for them to see and talk to each other. According to Willam Paisley (2014): "Communication is the fuel that keeps the fire of your relationship burning, without it, your relationship gets cold." Communication does not stop with face-to-face, it is inevitable. Hence, social media like Facebook will bridge that gap of communication. Future research coudl be done to highlight further effects of social media on interpersonal communication. 


\section{References}

\section{GOOGLE SCHOLAR}

Adler, P. S. (2008). Technological determinism. International Encyclopedia of Organization Studies, 4, 1536-9.

Al-Khaddam, H. K. (2013). Impact of Social Networks on Interpersonal Communication of the Students University College Irbid Girls: Facebook as a Model. Cross-Cultural Communication, 9(5), 17-22.

Burke, M., Adamic, L. A., \& Marciniak, K. (2013, June). Families on Facebook. In ICWSM. Lenhart, A. (2012). Teens, smartphones \& texting. Pew Internet \& American Life Project.

Ruggiero, T. E. (2000). Uses and gratification theory in the $21^{\text {st }}$ century. Mass communication \& society, 3(1), 3-37.

Selfhout, M. H., Branje, S. J., Delsing, M., ter Bogt, T.F., \& Meeus, W. H. (2009). Different types of Internet use, depression, and social anxiety: The role of perceived friendship quality. Journal of Adolescence, 32(4), 819-833.

Sheldon, P. (2008). Student favorite: Facebook motivates for its use. Southwestern Mass Communication Journal, 23(2), 39-53.

Steiner-Adair, C., \& Barker, T. H. (2013). The big disconnect: Protecting childhood and family relationships in the digital age. Harper Business.

Wiley, C., \& Sison, M. (2006, November). Ethics, accuracy and assumption: The use of Facebook by students and employers. In Southwestern Ohio Council for Higher Education Special Topics Forum, Dayton, OH.

Zuckerberg, M. (2012). Letter from Mark Zuckerberg. Form S-1: Registration Statement. Washington DC: United States Securities and Exchange Commission.

\section{PROQUEST}

Chan, T. K. H., Cheung, C. M. K., Shi, N., \& Lee, M. K. O. (2015). Gender Differences in Satisfaction with Facebook Users. Industrial Management \& Data Systems. 115(1), 182. Retrieved from http://search.proquest.com/docview/1647106568?accountid=173015.

Ellison, N. B., Steinfield, C., \& Lampe, C. (2007). The benefits of Facebook "friends" Social capital and college students' use of online social network sites. Journal of ComputerMediated communication, 12(4), 1143-1168.

Hills, T. S. D. (2015). Put your best face forward: Effects of media technologies on interpersonal communication of teenagers (Order No. 1605436). Available from ProQuest Dissertations \& Thesis Global. (1752253124). Retrieved from http://search.proquest.com/docview/1752253124?accountid=173015. 
Kuss, D. J., \& Griffiths, M. D. (2011). Online social networking and addiction-A review of the psychological literature. International Journal of Environmental Research and Public Health, 8(9), 3528-52. Retrieved from http://search.proquest.com/docview/899323305?accountid=173015.

Lenhart, A., Purcell, K., Smith, A., \& Zickuhr, K. (2010). Social Media \& Mobile Internet Use among Teens and Young Adults. Millennials. Pew internet \& American life project.

Shim, Y. S. (2007). The impact of Internet on teenagers' face-to-face communication. Global Media Journal, 6(10).

Vera, N. (2013). Quality of interpersonal communication in the digital media era. International Journal of Social Science and Humanity, 3(6), 565-n/a. doi:http://dx.doi.org/10.7763/IJSSH.2013.V3.304.

\section{PEWINTERNET.ORG}

Duggan, M. (2015, August 19). The Demographics of Social Media Users. Retrieved from Pew Research Center: http://www.pewinternet.org/2015/08/19/the-demographics-of-socialmedia-users/.

\section{PHILSTAR.COM}

Bondoc, J. (2014, October 6). OFW experience: At what cost to family? Retrieved from Philstar: http://www.philstar.com/opinion/2014/10/06/1376935/ofw-experience-what-costfamily.

\section{THEBOWENCENTER.ORG}

Kerr, Michael E. “One Family’s Story: A Primer on Bowen Theory”. The Bowen Center for the Study of the Family. 2000. http://www.thebowencenter.org.

\section{STATISTA.COM}

Mei-Pochtler, D. A. (2016). Leading global social networks 2016/Statista. Retrieved from Statista: hhtp://www.statista.com/statistics/272014/global-social-networks-ranked-by-numberof-users/.

\section{TWITTER.COM}

Paisley, William (2014). Personal Tweet. Retreived from

twitter.com/YourPocketGuru/status/508230860974592000 